\title{
MODEL PENGELOLAAN SAMPAH PERMUKIMAN DI KELURAHAN TUNJUNG SEKAR KOTA MALANG
}

\author{
Sudiro $^{1}$, Arief Setyawan ${ }^{2}$, Lukman Nulhakim ${ }^{3}$ \\ ${ }^{1,3}$ Teknik Lingkungan, Institut Teknologi Nasional Malang \\ ${ }^{2}$ Perencanaan Wilayah dan Kota, Institut Teknologi Nasional Malang \\ ${ }^{1}$ Email : sudiro_enviro@yahoo.co.id
}

Disetujui (accepted): 20 April 2018

\begin{abstract}
ABSTRAK
Kota Malang adalah salah satu wilayah di Jawa Timur yang menjadi tujuan wisata dengan pertumbuhuna penduduk yang meningkat dari tahun ke tahun. Sebagai kawasan perkotaan pertumbuhan fasilitas penunjang serta perdagangan dan jasa cukup pesat, sehingga penduduk juga semakin banyak. Akibatnya, adalah kepadatan penduduk semakin meningkat. Di sisi lain, aktifitas perkotaan dan komponennya termasuk penduduk, merupakan salah satu sumber sampah yang besar. Sehingga pengelolaan persampahan menjadi prioritas yang layak diutamakan. Di satu sisi pengelolaan sampah permukiman harus dilakukan sesuai dengan karakteristik wilayahnya agar optimal. Penelitian ini dilakukan dengan melakukan observasi langsung dilapangan terhadap aktivitas masyarakat dalam pengelolaan sampah, sarana dan prasarana pengelolaan sampah. Penelitian ini juga mengkaji timbulan sampah,komposisi serat karakteristik sampah. Berdasarkan hasil penelitian dan analisa dapat disampaiakan sebagai berikut : (1) Pola pengelolaan sampah sebagian besar masih menggunaakan pola KumpulAngkut-Buang, (2) Sarana dan Prasarana Pengelolaan sampah tersedia namun belum memadai jika dikaitkan dengan paradigma pengelolaan sampah yang lama (3) Timbulan sampah rata-rata sebesar 2,73 L/org.hari atau 0,28 kg/orang.hari (4) Komposisi sampahnya adalah organik basah 60,65\% dan 39,35\% Anorganik. (5) Keterlibatan masyarakat untuk mengelola sampah berbasis $3 R$ cukup signifikan. Berdasarkan kondisi seperti tersebut diatas dapat disimpulkan bahwa Model Pengelolaan Sampah di Tunjung Sekar dapat dilakukan dengan sistem $3 R$ berbasis masyarakat. Salah satu aplikasi dari model ini adalah dengan upaya daur ulang sampah yang dihasilkan.
\end{abstract}

Kata Kunci : sampah, permukiman, pengelolaan

\section{A. PENDAHULUAN}

Pertumbuhan penduduk cenderung semakin meningkat dari waktu ke waktu demikian juga terhadap Kota Malang. Kota Malang adalah salah satu wilayah di Jawa Timur yang merupakan bagian dari tujuan wisata. Berdasarkan tinjuan fungsionalnya wilayah ini adalah kawasan perkotaan. Oleh karena itu pertumbuhan fasilitas penunjang serta perdagangan dan jasa cukup pesat, maka penduduk juga semakin banyak menempati wilayah pusat - pusat perkotaan. Akibatnya, kepadatan penduduk semakin meningkat di wilayah yang bersangkutan. Di sisi lain bahwa, aktifitas perkotaan dan komponennya termasuk dalam hal ini penduduk, merupakan salah satu sumber sampah yang cukup besar. Oleh sebab itu pengelolaan persampahan menjadi prioritas utama. Di satu sisi 
pengelolaan sampah permukiman harus dilakukan sesuai dengan karakteristik wilayahnya agar optimal.

Pengelolaan sampah yang dilakukan di Kota Malang saat ini sebagian besar masih menggunakan paradigma lama, yaitu kumpul-angkut dan buang. Model pengeolalaan sampah yang demikian ini sebagian besar pelaksanaannya masih bertumpu pada pemerintah. Memang tidak dapat dipungkiri bahwa pemerintah berkewajiban memfasilitasi masyarakat dan komponennnya dalam upaya pengelolaan lingkungan. Model pengelolaan sampah tersebut memerlukan sarana dan prasarana yang harus memadai untuk mencapai kondisi optimal, sehingga sudah pasti diperlukan biaya yang tinggi.

Oleh karena sampah adalah dihasilkan dari aktivitas masyarakat, maka sudah seharusnya ditanamkan bahwa pengelolaan sampah juga menjadi tanggung jawab bersama. Sinergi antara masyarakat dengan pemerintah akan menghasilkan model pengelolaan sampah yang baik. Di satu sisi, berdasarkan letak geografis Kabupaten Malang, sangat diperlukan model pengelolaan sampah yang relevan dengan kondisi serta karakter wilayahnya. Penelitian ini dilakukan guna mendapatkan rumusan model pengelolaan sampah permukiman di Kelurahan Tunjungsekar, Kota Malang

\section{B. TINJAUAN PUSTAKA}

1. Kebijakan dan Strategi Nasional Pengembangan Sistem Pengelolaan Persampahan

Pada dasarnya pengelolaan sampah permukiman adalah merupakan bagian yang tak terpisahkan dalam hal pengelolaan sistem sanitasi. Dalam hal pengelolaan sampah secara nasional sudah dibuat suatu kebijakan dan strategi pelaksanaannya, seperti yang tercantum dalam Peraturan Menteri Pekerjaan Umum Nomor: 21/PRT/M/2006 Tentang Kebijakan Dan Strategi Nasional Pengembangan Sistem Pengelolaan Persampahan. Rumusan kebijakan tersebut antara lain adalah : (1) Pengurangan sampah semaksimal mungkin dimulai dari sumbernya. (2) Peningkatan peran aktif masyarakat dan dunia usaha/swasta sebagai mitra pengelolaan. (3) Peningkatan cakupan pelayanan dan kualitas sistem pengelolaan. (4) Pengembangan kelembagaan, peraturan dan perundangan. (5) Pengembangan alternatif sumber pembiayaan

\section{Konsep Pengelolaan Sampah Permukiman}

Berdasarkan PP No. 81 Tahun 2012 dinyatakan bahwa pengelolaan sampah adalah kegiatan yang sistematis, menyeluruh, dan berkesinambungan yang meliputi pengurangan dan penanganan sampah. Adapun upaya pengelolaan sampah meliputi (a) pengurangan sampah; (b). penanganan sampah. Dimana setiap orang wajib untuk melakukan pengurangan dan penangangan sampah. Berdasarkan Peraturan Menteri Pekerjaan Umum Republik Indonesia Nomor 03/PRT/M/2013 disampaikan bahwa penanganan sampah meliputi kegiatan: (a) pemilahan, (b) pengumpulan (c). pengangkutan; (d) pengolahan; dan (e). Pemrosesan akhir sampah. Sedangkan Pengolahan sampah meliputi kegiatan: (a) pemadatan, (b) pengomposan, (c). daur ulang materi, (d). mengubah sampah menjadi sumber energi. Dalam hal pelaksanaan pengolahan sampah beberapa hal 
yang menjadi pertimbangan adalah karakteristik sampah, teknologi pengolahan yang ramah lingkungan, keselamatan kerja, kondisi sosial masyarakat.

\section{METODE PENELITIAN}

Jelaskan jenis metode yang digunakan:kualitatif, kuatitatif atau mixed-method (Creswell, 2008); dan/atau kategori sifat penelitian: deskriptif, eksploratif atau eksplanatori (Groat \& Wang, 2002) disertai rincian metode pengumpulan data dan metode analisis data yang digunakan. Pada bagian ini juga dapat dijelaskan perspektif yang mendasari pemilihan metode tertentu.

\section{Pengumpulan Data}

Metode pengumpulan data yang digunakan, adalah survei, observasi lapangan dan sampling lapangan. Observasi dilakukan terhadap kondisi lahan, karakteristik serta penggunaan lahan eksisting. Metode sampling dengan menggunakan model grab sampling. Sampling lapangan ini dilakukan untuk mendapatkan data timbulan sampah,karakteritik serta komposisi sampah.

\section{Analisis Data}

Analisa data dilakukan dengan metode deskripitif - kualitatif. Metode deskriptif dilakukan untuk menjabarkan karakteristik wilayah dan potensipotensinya, menjabarkan ketersediaan sarana dan prasarana yang ada, menjabarkan kondisi eksisting persampahan dan pengelolaannya. Selajutnya, dilakukan analisa kualitatif guna merumuskan model pengelolaan sampah yang sesuai dengan karakteristik wilayah dan kondisi eksisting persampahan

\section{HASIL DAN PEMBAHASAN}

\section{Kondisi Eksisting Wilayah Kajian}

Secara administratif Kelurahan Tunjungsekar berada di wilayah Kecamatan Lowokwaru. Luas wilayah ini adalah $1907 \mathrm{~km}^{2}$, berasa pada $600 \mathrm{dpl}$. Kelurahan Tunjungsekar terbagi menjadi $8 \mathrm{RW}$ dan $73 \mathrm{RT}$. Adapun batas-batas wilayah Kelurahan Tunjungsekar adalah sebagai berikut : Kelurahan Mojolangu, Sebelah Barat berbatasan dengan Kelurahan Tunggulwulung dan Tasikmadu.

Tinjauan dari aspek lahan bahwa di Kawasan Tunjungsekar hampir sebagian besar adalah kawasan terbangun, dengan area terbuka tinggal sedikit. Fungsi kawasan terbangun ini adalah untuk permukiman, perkantoran dan perdagangan serta fasilitas umum. Area permukiman adalah penggunaan lahan terbesar di kawasan ini. Area terbuka yang masih ada terdiri dari sawah, tegalan dan taman

Seperti halnya kawasan lain jumlah penduduk di Kelurahan Tunjungsekar, mengalami peningkatan dari waktu ke waktu. Tahun 2012 sebanyak 16.374 jiwa, tahun 2013 sebanyak 16.519 jiwa, tahun 2014 sebanyak 16.648 jiwa, tahun 2015 sebanyak 16.903 jiwa, dan tahun 2016 sebanyak 17.067 jiwa (Monografi Kelurahan Tunjungsekar, 2017). Berikut adalah tabel yang menggambarkan distribusi penduduk di Kelurahan Tunjungsekar Kota Malang. 
Sudiro, Arief Setyawan dan Lukman Nulhakim, Model Pengelolaan Sampah Permukiman di Kelurahan Tunjung Sekar Kota Malang

Tabel 1. Jumlah penduduk Kelurahan Tunjungsekar tahun 2012-2016

\begin{tabular}{cccccc}
\hline \multirow{2}{*}{ RW } & \multicolumn{5}{c}{ Jumlah Penduduk (Jiwa) } \\
\cline { 2 - 6 } & $\mathbf{2 0 1 2}$ & $\mathbf{2 0 1 3}$ & $\mathbf{2 0 1 4}$ & $\mathbf{2 0 1 5}$ & $\mathbf{2 0 1 6}$ \\
\hline 01 & 2.112 & 2.128 & 2.131 & 2.134 & 2.149 \\
02 & 4.120 & 4.133 & 4.142 & 4.158 & 4.215 \\
03 & 2.041 & 2.038 & 2.051 & 2.052 & 2.025 \\
04 & 2.430 & 2.455 & 2.472 & 2.449 & 2.488 \\
05 & 1.721 & 1.790 & 1.910 & 1.935 & 1.967 \\
06 & 1.944 & 1.957 & 1.964 & 1.975 & 2.045 \\
07 & 1.160 & 1.168 & 1.171 & 1.175 & 1.168 \\
08 & 1.002 & 1.011 & 1.019 & 1.025 & 1.010 \\
\hline
\end{tabular}

Sumber Data : Profil Kelurahan Tunjungsekar 2012-2016

\section{Kondisi Eksisting Pengelolaan Sampah Permukiman di Kelurahan Tunjungsekar}

Model pengelolaan sampah yang dilaksanakan saat ini sebagian besar adalah kumpul-angkut-buang. Model pengelolaan sampah yang berlangsung saat ini sebagian besar adalah kumpul-angkut-buang. Namun di beberapa tempat masyarakatnya sudah berupaya untuk melakukan pengelolaan berbasis 3R. Salah satu kawasan tersebut adalah di RW 02,RW 04, dan RW 05. Sebagian besar masyarakat sudah berupaya untuk mengolah sampah organiknya menjadi kompos. Sedangkan untuk sampah Anorganik dikelola melalui Bank Sampah.

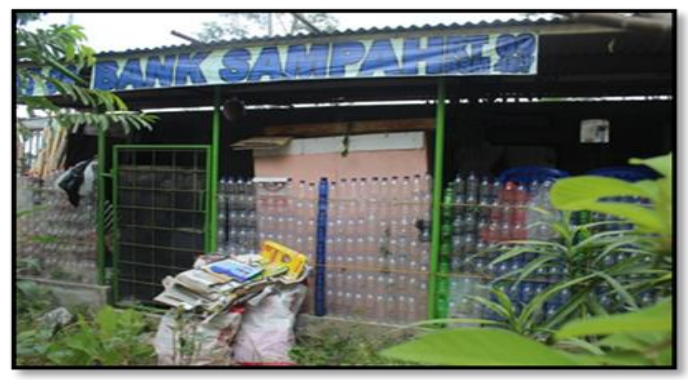

Gambar 1. Salah satu lokasi bank sampah di Tunjungsekar

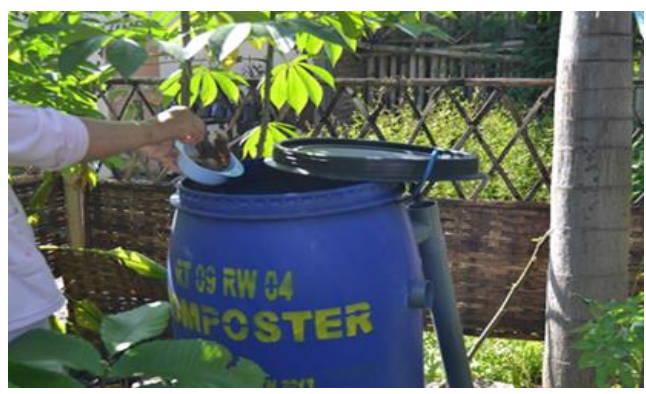

Gambar 2. Salah satu kegiatan pengomposan yang dilakukan oleh warga

\section{a. Sumber Penghasil Sampah}

Sumber sampah Permukiman di Kelurahan Tunjungsekar berasal dari (1) aktivitas domestik, (2) aktivitas non domestik. sumber sampah domestik berasal 
dari (i) hunian permanen (ii) hunian semi permanen (iii) hunian non permanen. sumber sampah non domestik berasal dari (i) perdagangan dan jasa, (ii) perkantoran, (iii) komersil (iv) fasilitas umum (v) fasilitas sosial. Berdasarkan Jenis sampah yang dihasilkan biasanya sisa makanan dan bahan sisa proses pengolahan makanan atau sampah basah (garbage), sampah kering (rubbish), perabotan rumah tangga, abu atau sisa tumbuhan kebun.

\section{b. Pola Pewadahan dan Pengumpulan}

Ada dua jenis pewadahan sampah yang digunakan oleh sebagain besar masyarakat Tunjungsekar. Dua jenis tempat sampah tersebut yaitu (a) permanen berupa tembok yang terbuat dari olahan semen, (b) semi permanen yang berupa tempat sampah karet, kaleng/ember bekas cat dan bin teruat dari plastik. Tempat sampah permanen berupa tembok yang terbuat dari olahan semen terdapat di area perumahan permanen yang memiliki lahan yang cukup luas dan membutuhkan biaya yang cukup besar untuk membangun tempat sampah ini.

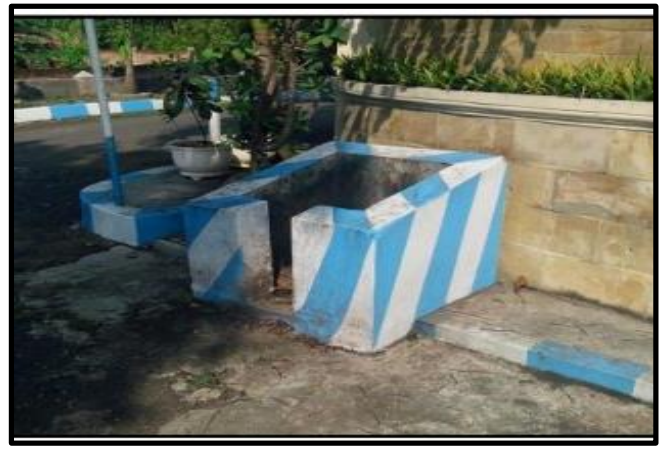

Gambar 3. Tempat Sampah Permanen

Tempat sampah semi permanen yang berupa wadah sampah karet sering ditemukan di area rumah semi permanen dan non permanen.
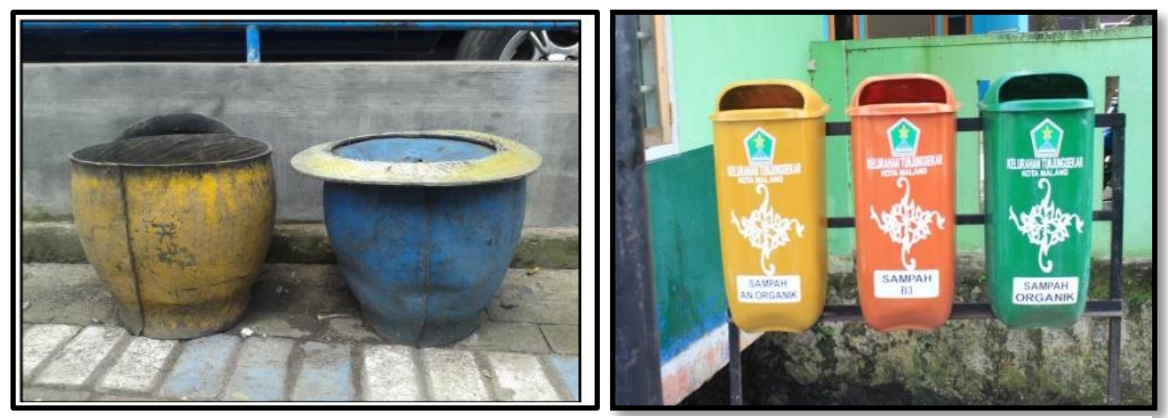

Gambar 4. Tempat Sampah Semi Permanen

Tahap pengumpulan sampah di Kelurahan Tunjungsekar dilakukan dengan menggunakan gerobak dorong, baik gerobak dorong yang dioperasikan secara manual maupun gerobak dorong yang dioperasikan dengan sepeda motor. Petugas yang melakukan pelayanan pengangkutan sampah dari tiap rumah dilakukan oleh petugas swasta atau warga setempat yang dibayar oleh setiap RT yang 
Sudiro, Arief Setyawan dan Lukman Nulhakim, Model Pengelolaan Sampah Permukiman di Kelurahan Tunjung Sekar Kota Malang

bersangkutan, sehingga setiap RT di Kelurahan Tunjungsekar melakukan koordinasi masing - masing kepada warganya dengan membayar retribusi untuk pelayanan pengumpulan sampah.

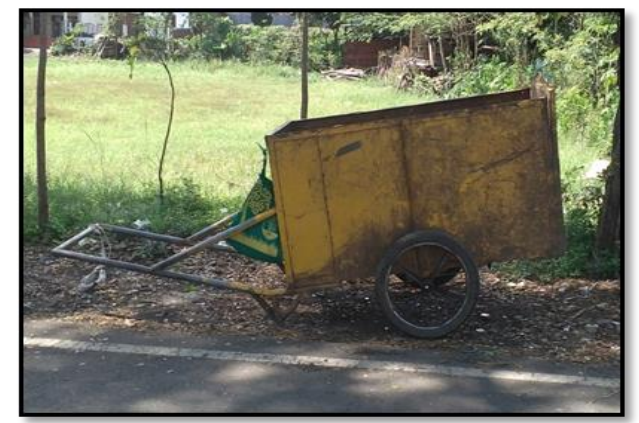

Gambar 5. Gerobak Dorong

\section{c. Pengelolaan Sementara}

Sebagian besar pola pengelolaan sampah dilakukan dengan paradigma lama. Dimana pola demikian ini masih mengandalkan model KUMPUL-ANGKUTBUANG. Pada pelaksanaan model ini, salah satu prasarana yang dibutuhkan adalah Tempat Pengelolaan Sementara (TPS). TPS yang tersedia di Kelurahan Tunjungsekar ada 1 unit, yang terletak di Jalan Ikan Piranha tepatnya berada disamping Kantor Kelurahan. TPS ini mempunyai luas bangunan sebesar $72 \mathrm{~m}^{2}$. Pengelolaan yang dilakukan pada kedua TPS ini masih konvensional saja, yaitu TPS hanya berfungsi sebagai penampungan sementara.

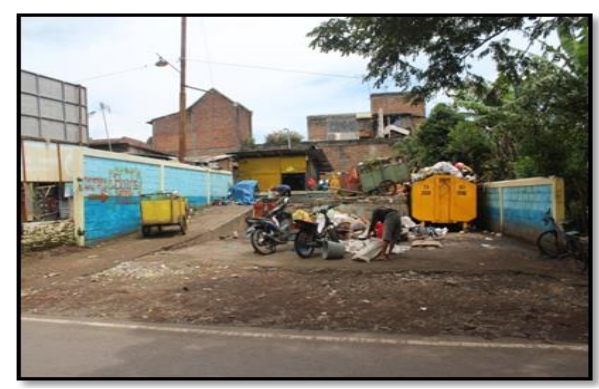

Gambar 6. Tempat pengelolaan sementara

\section{d. Pengangkutan dan Pembuangan Akhir}

Sampah yang ada di TPS Tunjungsekar diangkut ke TPA Supit Urang dengan menggunakan alat pengangkutan sampah yang berupa arm roll truck. TPA Supit Urang adalah satu satunya TPA di Kota Malang yang digunakan untuk pemrosesan akhir sampah.

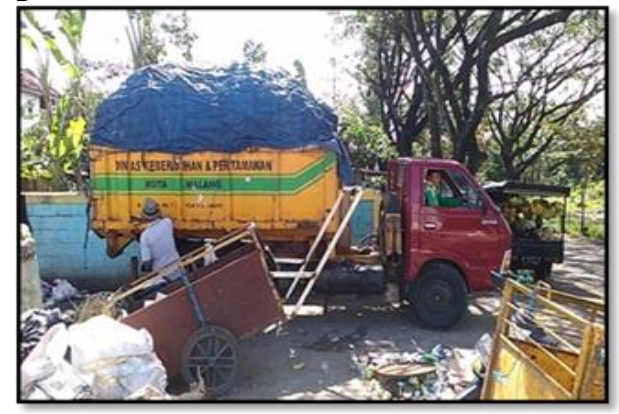

Gambar 7. Tempat pengangkutan dan pengelolaan akhir 
Sudiro, Arief Setyawan dan Lukman Nulhakim, Model Pengelolaan Sampah Permukiman di Kelurahan Tunjung Sekar Kota Malang

\section{Timbulan Sampah}

Timbulan sampah permukiman diukur dan dihitung terhadap tiga kelompok hunian di Kelurahan Tunjungsekar, yaitu hunian permanen, semi permanen dan non permanen, dengan besaran timbulan sampah dilakukan selama 7 hari berturut turut. Jumlah sampel total sebesar 28 titik,dengan 11 titik pada hunian permanen, 12 titik pada hunian semi permanen dan 5 titik sampel pada hunian non permanen.

Tabel 2. Hasil sampling timbulan sampah pada hunian permanen

\begin{tabular}{clcccc}
\hline No & Hari & $\begin{array}{c}\text { Jumlah } \\
\text { Sampel }\end{array}$ & $\begin{array}{c}\text { Jumlah } \\
\text { jiwa }\end{array}$ & $\begin{array}{c}\text { Berat Sampah } \\
\text { (kg/org.hari) }\end{array}$ & $\begin{array}{c}\text { Timbulan Sampah } \\
\text { (L/org.hari) }\end{array}$ \\
\hline 1 & Senin & 11 & 41 & 0.29 & 1.53 \\
2 & Selasa & 11 & 41 & 0.25 & 2.89 \\
3 & Rabu & 11 & 41 & 0.39 & 2.19 \\
4 & Kamis & 11 & 41 & 0.31 & 1.98 \\
5 & Jumat & 11 & 41 & 0.28 & 3.27 \\
6 & Sabtu & 11 & 41 & 0.29 & 2.24 \\
7 & Minggu & 11 & 41 & 0.32 & 2.45 \\
\hline & & & Rata-rata & $\mathbf{0 , 3 0}$ & $\mathbf{2 , 3 7}$
\end{tabular}

Sumber: Hasil Survei, 2017

Tabel 3. Hasil sampling timbulan sampah pada hunian semi permanen

\begin{tabular}{clcccc}
\hline No & Hari & $\begin{array}{c}\text { Jumlah } \\
\text { Sampel }\end{array}$ & $\begin{array}{c}\text { Jumlah } \\
\text { Jiwa }\end{array}$ & $\begin{array}{c}\text { Berat Sampah } \\
\text { (kg/org.hari) }\end{array}$ & $\begin{array}{c}\text { Timbulan Sampah } \\
\text { (L/org.hari) }\end{array}$ \\
\hline 1 & Senin & 12 & 52 & 0.25 & 1.77 \\
2 & Selasa & 12 & 52 & 0.20 & 1.82 \\
3 & Rabu & 12 & 52 & 0.26 & 1.54 \\
4 & Kamis & 12 & 52 & 0.22 & 1.81 \\
5 & Jumat & 12 & 52 & 0.18 & 2.27 \\
6 & Sabtu & 12 & 52 & 0.18 & 2.87 \\
\hline 7 & Minggu & 12 & 52 & 0.17 & 1.95 \\
\hline & & & Rata-rata & $\mathbf{0 , 2 1}$ & $\mathbf{2 , 0 0}$ \\
\hline
\end{tabular}

Sumber: Hasil Survei, 2017

Tabel 4. Hasil sampling timbulan sampah pada hunian non permanen

\begin{tabular}{clcccc}
\hline No & Hari & $\begin{array}{c}\text { Jumlah } \\
\text { Sampel }\end{array}$ & $\begin{array}{c}\text { Jumlah } \\
\text { Jiwa }\end{array}$ & $\begin{array}{c}\text { Berat Sampah } \\
\text { (kg/org.hari) }\end{array}$ & $\begin{array}{c}\text { Volume Sampah } \\
\text { (L/org.hari) }\end{array}$ \\
\hline 1 & Senin & 5 & 22 & 0.17 & 2.17 \\
2 & Selasa & 5 & 22 & 0.12 & 2.29 \\
3 & Rabu & 5 & 22 & 0.13 & 2.15 \\
4 & Kamis & 5 & 22 & 0.12 & 1.58 \\
5 & Jumat & 5 & 22 & 0.10 & 1.25 \\
6 & Sabtu & 5 & 22 & 0.15 & 1.44 \\
7 & Minggu & 5 & 22 & 0.14 & 1.47 \\
\hline & & & Rata-rata & $\mathbf{0 , 1 3}$ & $\mathbf{1 , 7 7}$ \\
\hline
\end{tabular}

Sumber: Hasil Survei, 2017 
Sudiro, Arief Setyawan dan Lukman Nulhakim, Model Pengelolaan Sampah Permukiman di Kelurahan Tunjung Sekar Kota Malang

Besaran timbulan sampah dalam satuan berat di Kelurahan Tunjungsekar:

- Rerata berat sampah sampah yang diukur untuk rumah permanen $=0,30 \mathrm{~kg} / \mathrm{org} / \mathrm{hr}$

- Rerata berat sampah sampah yang diukur untuk rumah semi permanen $=0,21 \mathrm{~kg} / \mathrm{org} / \mathrm{hr}$

- Rerata berat sampah sampah yang diukur nrumah non permanen = $0,13 \mathrm{~kg} / \mathrm{org} / \mathrm{hr}$

Jadi besar timbulan sampah di Kelurahan Tunjungsekar adalah

$=\frac{100}{75} x \frac{(0,30+0,21+0,13)}{3} \mathrm{~kg} / \mathrm{org} / \mathrm{hr}$

$=0,28 \mathrm{~kg} / \mathrm{org} / \mathrm{hr}$

(Berdasarkan rumus dari SNI 19-3964-1994)

Besaran timbulan sampah dalam satuan volume di Kelurahan Tunjungsekar

- Rerata volume sampah sampah yang diukur untuk rumah permanen $=2,37 \mathrm{ltr} / \mathrm{org} / \mathrm{hr}$

- Rerata volume sampah sampah yang diukur untuk rumah semi permanen $=2,00 \mathrm{ltr} / \mathrm{org} / \mathrm{hr}$

- Rerata volume sampah sampah yang diukur untuk rumah non permanen $=1,77 \mathrm{ltr} / \mathrm{org} / \mathrm{hr}$

Jadi besar timbulan sampah di Kelurahan Tunjungsekar adalah

$=\frac{100}{75} x \frac{(2,37+2,00+1,77)}{3} \mathrm{ltr} / \mathrm{org} / \mathrm{hr}$

$=2,73 \mathrm{ltr} / \mathrm{org} / \mathrm{hr}$

(Berdasarkan rumus dari SNI 19-3964-1994)

Berdasarkan analisa tersebut dapat diketahui bahwa rata - rata timbulan sampah domestik untuk di wilayah Malang Barat ini adalah sebesar 2,73 liter/orang.hari. Besaran ini masuk dalam katagori besar.

\section{Analisa Komposisi Sampah}

Komposisi sampah di Kelurahan Tunjungsekar sangat bervariasi. Berikut adalah nilai rata-rata komposisi sampah dari ketiga kelompok hunian.

Tabel 5. Analisa komposisi sampah

\begin{tabular}{|c|c|c|c|c|c|c|}
\hline \multirow{2}{*}{ No } & \multirow{2}{*}{$\begin{array}{c}\text { Jenis } \\
\text { Sampah }\end{array}$} & \multirow{2}{*}{ Sub Jenis } & \multicolumn{3}{|c|}{ Jenis Rumah } & \multirow{2}{*}{ Rata-rata } \\
\hline & & & Permanen & Semi Permanen & Non Permanen & \\
\hline \multirow{2}{*}{1} & \multirow{2}{*}{$\begin{array}{l}\text { Sampah } \\
\text { Organik }\end{array}$} & $\begin{array}{l}\text { Sisa } \\
\text { Makanan }\end{array}$ & $53,50 \%$ & $57,20 \%$ & $52,50 \%$ & $54,4 \%$ \\
\hline & & $\begin{array}{l}\text { Sampah } \\
\text { Kebun }\end{array}$ & $5,00 \%$ & $5,60 \%$ & $7,90 \%$ & $6,2 \%$ \\
\hline \multirow{4}{*}{2} & \multirow{4}{*}{ Plastik } & PET & $5,00 \%$ & $4,00 \%$ & $2,70 \%$ & $3,9 \%$ \\
\hline & & HDPE & $1,20 \%$ & $1,40 \%$ & $0,00 \%$ & $0,9 \%$ \\
\hline & & $\mathrm{PVC}$ & $0,00 \%$ & $0,00 \%$ & $0,80 \%$ & $0,3 \%$ \\
\hline & & LDPE & $9,80 \%$ & $13,20 \%$ & $14,90 \%$ & $12,6 \%$ \\
\hline
\end{tabular}


Sudiro, Arief Setyawan dan Lukman Nulhakim, Model Pengelolaan Sampah Permukiman di Kelurahan Tunjung Sekar Kota Malang

\begin{tabular}{|c|c|c|c|c|c|c|}
\hline & & PP & $5,40 \%$ & $3,10 \%$ & $5,20 \%$ & $4,6 \%$ \\
\hline & & PS & $4,00 \%$ & $2,40 \%$ & $2,50 \%$ & $3,0 \%$ \\
\hline & \multirow{4}{*}{ Kertas } & Kertas & $4,30 \%$ & $6,50 \%$ & $4,00 \%$ & $4,9 \%$ \\
\hline & & Koran & $1,20 \%$ & $0,30 \%$ & $0,00 \%$ & $0,5 \%$ \\
\hline 3 & & Kardus & $0,30 \%$ & $0,80 \%$ & $0,00 \%$ & $0,4 \%$ \\
\hline & & Karton & $3,90 \%$ & $2,70 \%$ & $1,80 \%$ & $2,8 \%$ \\
\hline 4 & Kain & Kain & $0,00 \%$ & $0,70 \%$ & $0,00 \%$ & $0,2 \%$ \\
\hline 5 & Karet & Karet & $0,00 \%$ & $0,00 \%$ & $0,00 \%$ & $0,0 \%$ \\
\hline 6 & Kayu & Kayu & $0,70 \%$ & $0,10 \%$ & $0,00 \%$ & $0,3 \%$ \\
\hline 7 & Logam & Logam & $0,00 \%$ & $0,20 \%$ & $0,00 \%$ & $0,1 \%$ \\
\hline 8 & Kaca & Kaca & $0,20 \%$ & $0,30 \%$ & $0,00 \%$ & $0,2 \%$ \\
\hline 9 & B3 & B3 & $0,00 \%$ & $0,00 \%$ & $0,00 \%$ & $0,0 \%$ \\
\hline 10 & Diapers & Diapers & $3,20 \%$ & $0,30 \%$ & $0,00 \%$ & $1,2 \%$ \\
\hline 11 & Lain-lain & Lain-lain & $2,40 \%$ & $1,30 \%$ & $7,60 \%$ & $3,8 \%$ \\
\hline
\end{tabular}

Sumber : hasil analisis, 2017

\section{Aspek Sosial, Ekonomi dan Peran Masyarakat.}

Pada prinsipnya sebagian besar masyarakat Tunjungsekar sudah sadar akan cara mengelola sampah dengan baik. Salah satu indikatornya adalah bahwa sebagin besar sudah membuang sampahnya ke tempat yang tersedian. Namun demikain masih ada juga yang membuang sampah ke sungai, dengan alasan tidah ada tempat. Tinjauan terhadap kebiasaan masyarakat dalam membuang sampah tergambar dalam grafik berikut :

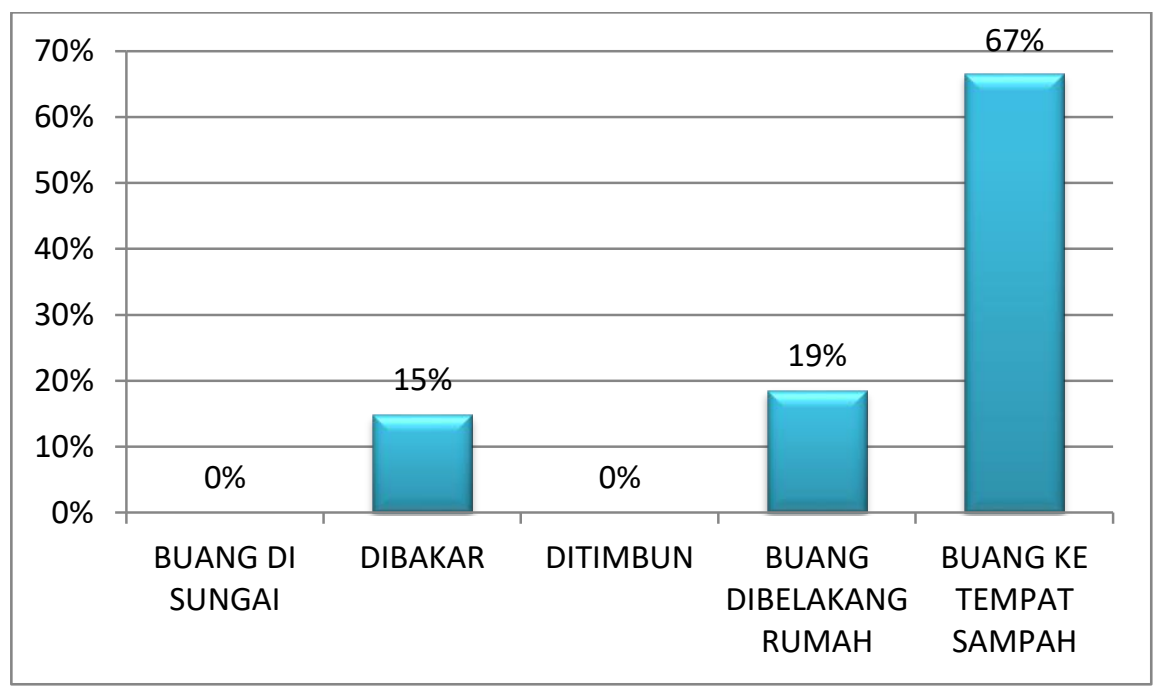

Gambar 8. Kebiasaan masyarakat dalam membuang sampah

Sebagian masyarakat Tunjungsekar sebenarnya sudah memahami tentang konsep pengelolaan sampah dengan prinsip 3R . Berdasarakan kuisioner yang dilakukan menyatakan bahwa $30 \%$ sudah paham, 30\% Tidak paham, 37\% raguragu. Berdasarkan data tersebut tentu saja menjadi modal yang positip untuk implementasi pengelolaan sampah dengan prinsip 3R. 
Sudiro, Arief Setyawan dan Lukman Nulhakim, Model Pengelolaan Sampah Permukiman di Kelurahan Tunjung Sekar Kota Malang

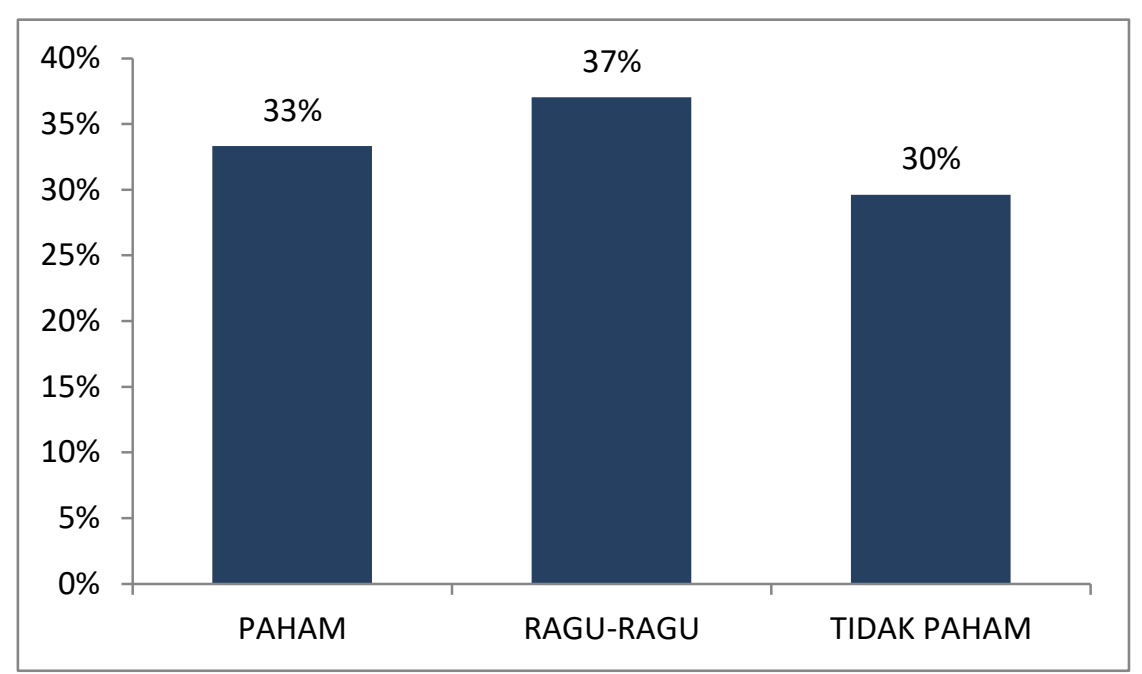

Gambar 9. Tingkat pemahaman masyarakat tentang konsep pengelolaan sampah

Namun demikian pemahaman ini harus diimbangi dengan pelaksanaan cara memperlakukan sampah oleh masyarakat sendiri. Berdasarkan survey yang dilakukan masyarakat Tunjungsekar sebagian sudah melakukan pembuangan sampah dengan cara terpisah, yaitu sebesar 33\%. Namun $67 \%$ masih melakukan pembuangan sampah secara tercampur (basah dan kering). Hal ini terjadi karena tidak adanya sarana dan prasarana yang dimiliki, serta tidak ada pengetahuan yang merata tentang tindak lanjut apa yang dapat dilakukan

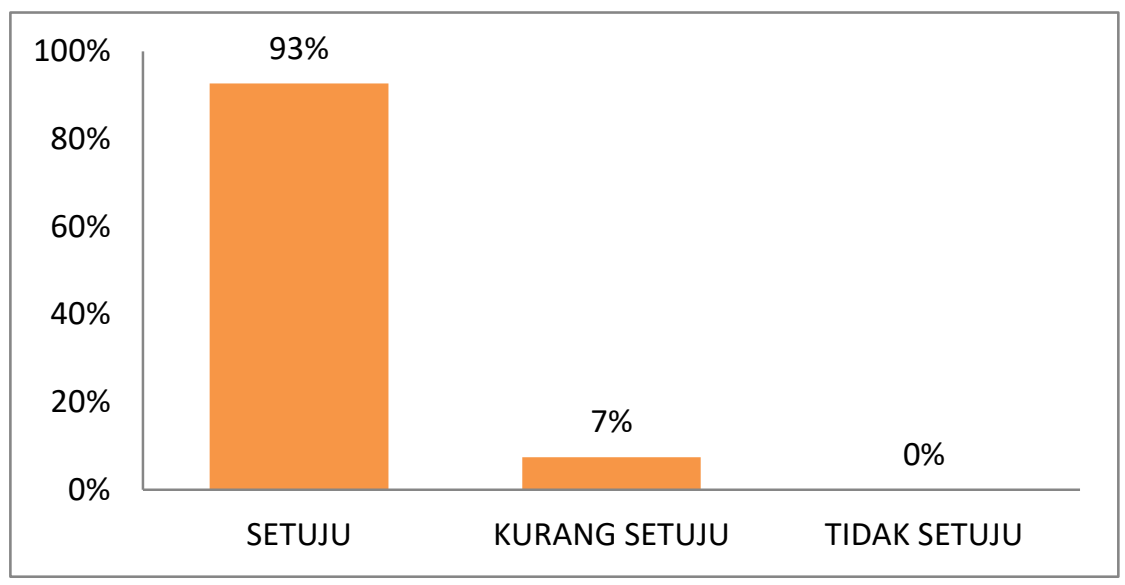

Gambar 10. Minat masyarakat untuk memilah sampah

\section{Perilaku Masyarakat Tunjungsekar dalam memperlakukan Sampah}

Di satu sisi terdapat hal positip yang ditemui pada masyarakat Tunjungsekar, yaitu bahwa terdapat potensi partisipasi masyarakat untuk mengelola sampah dengan baik dan benar. Masyarakat adalah elemen penting yang akan mempengaruhi kesuksesan dalam sistem pengelolaan sampah. Minat masyarakat untuk daur ulang sampah cukup besar. Berdasarkan observasi yang dilakukan pada setiap wilayah RW di Kelurahan Tunjungsekar diketahui bahwa masyarakat 
mulai sadar akan pentingnya memilah sampah sejak dari sumbernya. Masyarakat juga sudah mulai memanfaatkan sampah organik atau sampah basah seperti sisa makanan, sayuran dan sampah kebun untuk membuat kompos. Beberapa wilayah tersebut antara lain adalah di RT 09 RW 04 dan RT 01 RW 05 hampir disetiap gang sudah tersedia tong komposter. Sedangkan sampah anorganik atau sampah kering seperti bekas botol minuman, kardus, kertas serta logam dijual ke bank sampah yang sudah ada seperti di RT 05, RT 09 RW 04 dan RT 01 RW 05. Namun hal ini masih berjalan hanya dibeberapa RT saja. Sehingga sejauh ini peran serta masyarakat dalam mengelola sampah masih kurang, tetapi potensinya ada.

\section{E. KESIMPULAN}

Pola pengelolaan sampah sebagian besar masih menggunaakan pola KumpulAngkut-Buang. Timbulan sampah rata-rata sebesar 2,73 L/org.hari atau 0,28 $\mathrm{kg}$ /orang.hari dengan komposisi sampahnya adalah organik basah $60,65 \%$ dan 39,35\% Anorganik. Keterlibatan masyarakat untuk mengelola sampah berbasis 3R cukup signifikan. Model Pengelolaan Sampah di Tunjung Sekar dapat dilakukan dengan sistem 3R berbasis masyarakat. Rekomendasi model pengelolaan sampah ini didasarkan pada beberapa aspek, yaitu, Timbulan sampah,karakteristik sampah,Komposisi sampah, pemahaman masyarakat, tingkat kemauan masyarakat serta karakteristik lahan. Rekomendasi ini dilakukan juga berdasarkan potensi yang dimiliki oleh masyarakat tersebut. Berdasarkan komponen tersebut diatas maka model pengelolaan sampah yang dilakukan oleh Tunjungsekar harus sudah mulai beralih menuju ke konsep 3R. Adapun implemtasinya adalah pengeloaan sampah tidak semua menggunakan pola lama, yaitu kumpul-angkut-buang, dan engelolaan sampah harus dengan memperhatikan aspek manfaat, yaitu reuserecycle-reduce.

\section{DAFTAR PUSTAKA}

Anonim. 2006. Peraturan Menteri Pekerjaan Umum No. 21 Tahun 2006 tentang Kebijakan Dan Strategi Nasional Sistem Pengelolaan Persampahan. Kementerian Pekerjaan Umum.

Anonim. 2008. Undang - Undang No. 18 Tahun 2008 Tentang Pengelolaan Sampah. Pemerintah Republik Indonesia.

Anonim. 2017. Monografi Kelurahan Tunjungsekar.

Anonim. 2012. Peraturan Pemerintah No. 81 Tahun 2012 tentang Pengelolaan Sampah Rumah Tangga Dan Sampah Sejenis Sampah Rumah Tangga. Pemerintah Republik Indonesia.

Anonim. 2013. Peraturan Menteri Pekerjaan Umum No. 3 Tahun 2013 tentang Penyelenggaraan Prasarana Dan Sarana Persampahan Dalam Penanganan Sampah Rumah Tangga Dan Sampah Sejenis Sampah Rumah Tangga. Kementerian Pekerjaan Umum.

Hariastuti, Niluh Putu. 2013. Pemodelan Sistem Normatif Pengelolaan Sampah Kota. Jurnal IPTEK Vol 17 No.1 Mei 2013. 
Sudiro, Arief Setyawan dan Lukman Nulhakim, Model Pengelolaan Sampah Permukiman di Kelurahan Tunjung Sekar Kota Malang

Jumar, dkk. 2014. Strategi Pengelolaan Sampah Rumah Tangga Di Kelurahan Lok Bahu Kecamatan Sungai Kunjang Kota Samarinda. eJournal Administrative Reform. Volume 2, Nomor 1, 2014: 771-782.

Ruslinda, Yenni., dkk. 2012. Studi Timbulan, Komposisi Dan Karakteristik Sampah Domestik Kota Bukittinggi. Jurnal Teknik Lingkungan UNAND 9 (1), $2012: 1-12$.

Wahyuni, Endah Tri., dkk. 2014. Optimalisasi Pengelolaan Sampah Melalui Partisipasi Masyarakat an Kajian Extended Producer Responsibility (EPR) Di Kabupaten Magetan. Jurnal EKOSAINS Volume VI No. 1 Maret 2014.

Yogiesti , Viradin.,dkk. 2010. Pengelolaan Sampah Terpadu Berbasis Masyarakat Kota Kediri. Jurnal Tata Kota dan Daerah Volume 2, Nomor 2, Desember 2010. 